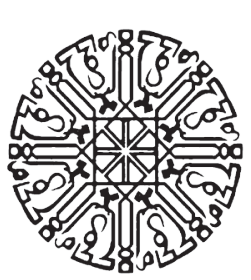

\title{
Perda Syariah Perspektif Ketatanegaraan dan Siyasah Dusturiyyah
}

\author{
Cholida Hanum \\ IAIN Salatiga \\ cholidahanum@iainsalatiga.ac.id
}

\begin{abstract}
One of the results of Indonesian reform was the fundamental change in constitutional system which was originally centralized to be decentralized. It is undeniable that the decentralization system opened the faucet for the emergence of Sharia Perda. In addition, these Regulations appear related to the historicity of the application of the Islamic Shariah in Indonesia since Islam entered the archipelago. Some of the contents of sharia regulations are contrary to the provisions in the principles of human rights both contained in human rights in the Islamic and human rights perspective contained in the Indonesian constitution. The main principle in the teachings of Islam is the benefit of society which is contained in the Qur'an and the Sunnah. The implementation of legislation including regional regulations which are the lowest level in the hierarchy of legislation must realize the basic goals of this country, namely protection of the rights of citizens and in the concept of dusturiyyah siyasah it is also stipulated that regulations must guarantee the benefit of society as the main goal in Islamic nomocracy.
\end{abstract}

Keywords: Sharia Perda, Siyasah Dusturiyyah, Kemaslahatan

\section{Latar Belakang Masalah}

Semenjak bergulirnya reformasi sebagai pengejawantahan sistem demokrasi di Indonesia, telah memberikan dorongan yang sangat kuat bagi daerah untuk mengurus daerahnya sesuai dengan aspirasi masyarakat di daerah. Dengan adanya otonomi daerah, kemudian daerah berlomba-lomba untuk mengatur segala urusan yang berkaitan dengan daerahnya ke dalam Peraturan Daerah. Secara substansial, otonomi daerah memang merupakan konsensus politik antara pusat dan daerah yang memberikan peluang sebesarbesarnya dan seluas-luasnya bagi daerah untuk mengelola daerahnya sendiri. Bahkan negara telah mengakomodir hadirnya daerah-daerah yang bersifat khusus atau bersifat istimewa sebagaimana tertuang dalam Pasal 18 ayat (1) UUD 1945. 
Namun berbagai polemik muncul atas pemberlakuan peraturan daerah tersebut di berbagai daerah karena dinilai melanggar amanat konstitusi dan ideologi negara, yaitu Pancasila sebagai dasar fundamental negara Indonesia. Yang paling signifikan di Era Reformasi ini bahwa mayoritas warga negara Indonesia yang beragama islam memiliki pengaruh kuat di daerah, hal tersebut ditandai dengan munculnya fenomena produk hukum Peraturan Daerah berperspektif syariah islam. Berbagai polemik muncul atas pemberlakuan peraturan daerah tersebut di berbagai daerah karena dinilai melanggar amanat konstitusi dan ideologi negara, yaitu Pancasila sebagai dasar fundamental negara Indonesia.

Selain itu, Peraturan Daerah berperspektif syariat Islam juga juga diindikasikan berpotensi melahirkan Pelanggaran Hak Asasi Manusia dan Perpecahan bangsa. Misalnya pada Peraturan daerah di aceh atau yang sering disebut sebagai yang dalam kenyataannya syarat dengan pelanggaran hak asasi manusia. Berdasarkan urian tersebut, maka tulisan ini akan membahas terkait Perda Syariah dengan beragam problematikanya dan sekaligus merespon adanya perda-perda syariah yang tidak kunjung tuntas. Berdasarkan latar belakang tersebut, penulis akan menjawab berbagai permasalahan dalam tulisan ini yakni: bagaimana konsepsi munculnya Perda Syariah di Indonesia dan bagaimanakah keberadaan Perda Syariah dalam konsteks Ketatanegaraan Indonesia dan Siyasah Dusturiyyah.

\section{Metode Penelitian}

Jenis penelitian ini merupakan penelitian kualitatif yang menggunakan metode pendekatan yuridis normatif dengan melakukan kajian peraturan perundang-undnagan dan literatur yang berhubungan dengan permasalahan. Jenis data yang digunakan dalam penilitian ini adalah data sekunder yang terdiri dari bahan hukum primer yaitu peraturan perundang-undangan dan bahan hukum sekunder yakni buku-buku, jurnal, dokumen, data elektronik serta artikel-artikel yang mendukung penelitian ini. Sedangkan bahan hukum tersier terdiri dari ensiklopedia dan kamus.

\section{Perda Syariah di Indonesia}

Peraturan Daerah (Perda) Syariah merupakan peraturan yang bermuatan nilainilai dan atau norma-norma Islam yang bersumber pada Al-Qur'an dan Hadits yang mana peraturan ini berlaku di suatu daerah (Suntana 2014). Dalam Hierarki peraturan perundangundangan, Perda merupakan urutan terandah tata hukum di Indonesia. Sejalan dengan prinsip dalam konstitusi negara Indonesia sebagai sebuah negara hukum. Sangatlah penting untuk melihat ke dalam dinamika posisi syariah Islam dalam konstelasi konstitusi hukum negara apalagi jika dikontekskan dengan otonomi daerah. Meskipun otonomi dimaknai secara harfiah sebagai bentuk independensi, namun harus dijalankan secara bertanggungjawab kepada pusat.

\footnotetext{
al-aḥkām vol. 4, Nomor 2, 2019
} 
Apalagi agama termasuk dalam enam urusan yang menjadi tugas pemerintah pusat dan bukanlah domain daerah sehingga sangatlah menarik untuk melihat dinamika syariah dalam hukum nasional dan juga hukum lokal. Namun menjadi sebuah permasalahan apabila, syariah justru menjadi alat penguasa lokal yang tentunya sudah menjadi sebuah distorsi dalam implementasi syariah (Jati 2013). Mengenai Peraturan Daerah yang bertujuan untuk mengakomodir seluruh kondisi yang secara khusus dimiliki masing-masing daerah dalam rangka penyelenggaraan otonomi daerah dan tugas pembantuan (Republik Indonesia 2011). Dalam penjelasan Pasal 7 ayat (1) huruf g Undang-Undang No. 12 tahun 2011 tentang Pembentukan Peraturan Perundang-Undangan dijelaskan bahwa termasuk dalam peraturan daerah provinsi dan peraturan daerah kabupaten/kota adalah qanun yang berlaku di Provinsi Aceh dan perdasus serta perdasi yang berlaku di Provinsi Papua dan Provinsi Papua Barat.

Di dalam Undang-Undang No. 23 tahun 2014 sebagaimana diubah melalui Perpu No. 2 tahun 2014 yang kemudian disahkan menjadi Undang-Undang No. 2 tahun 2015 dan diubah kembali melalui Undang-Undang No. 9 tahun 2015 tentang Pemerintahan Daerah, pengertian dari otonomi daerah secara jelas diartikan yakni hak, wewenang, dan kewajiban daerah otonom untuk mengatur dan mengurus sendiri urusan pemerintahan dan kepentingan masyarakat setempat dalam sistem Negara Kesatuan Republik Indonesia. Dalam bentuk implementasi dari otonomi daerah itu, terdapat pula satuan-satuan pemerintahan daerah yang mana bersifat khusus dan istimewa.

Salah satu bentuk dari satuan pemerintahan daerah yang bersifat khusus adalah Pemerintahan Aceh yang kekhususannya telah diatur dalam TAP No. IV/MPR/1999 yang kemudian dikuti dengan pembentukan Undang-Undang No. 18 Tahun 2001 tentang Otonomi Khusus bagi Provinsi Nanggroe Aceh Darussalam. Undang-Undang ini pada dasarnya mengatur kewenangan yang bersifat khusus kepada Pemerintah Aceh yang berbeda dari kewenangan pemerintah daerah-daerah lainnya sebagaimana diatur dalam UndangUndang No. 32 Tahun 2004 dan Undang-Undang No. 33 Tahun 2004. Undang-Undang No. 18 Tahun 2001 itu kemudian dicabut dan diubah dengan UU No. 11 Tahun 2006 tentang Pemerintahan Aceh (UUPA).

UUPA merupakan hasil kesadaran yang kuat dari Pemerintah dan Gerakan Aceh Merdeka (GAM) melalui penandatanganan Nota Kesepahaman (Memorandum of Understanding) pada tanggal 15 Agustus tahun 2005, guna menyelesaikan konflik secara damai, berkelanjutan, menyeluruh, dan bermartabat dalam bingkai NKRI. Nota Kesepahaman tersebut merupakan sebuah bentuk rekonsiliasi secara bermartabat untuk menuju pembangunan sosial, ekonomi, dan politik di Aceh secara berkelanjutan (Felix 2011). 
Pada dasarnya pengaturan mengenai pemerintahan yang bersifat istimewa/khusus telah terakomodir pula dalam konstitusi yaitu tepatnya pada Pasal 18 ayat (1) UndangUndang Dasar 1945. Dalam implementasinya dibeberapa daerah di Indonesia khususnya di Aceh telah pula mendapatkan pengakuan secara yuridis sebagaimana yang diamanatkan dalam TAP No. IV/MPR/1999 dan kemudian dikuti dengan pembentukan UU No. 18 Tahun 2001 tentang Otonomi Khusus bagi Provinsi Nanggroe Aceh Darussalam, kemudian diubah melalui Undang-Undang No. 11 tahun 2006 tentang Pemerintahan Aceh. Salah satu produk hukum yang dilahirkan Pemerintahan Daerah Aceh adalah berupa Qanun yang kemudian keberadaannya dipersamakan dengan Peraturan Daerah secara umum, karena dibentuk pula oleh DPR yang bernama DPRA (Dewan Perwakilan Rakyat Aceh) bersama dengan Gubernur.

\section{Problematika Perda Syariah}

Formalisasi syariah Islam di beberapa produk hukum daerah di Indonesia menyisakan fenomena yang unik untuk dikaji misalnya di Provinsi Nangroe Aceh Darussalam; Bima, Nusa Tenggara Barat; di Kabupaten Bulukumba Sulawesi Selatan; Indramayu, Tasikmalaya,dan Cianjur, Jawa Barat; Banten, Kota Tangerang, dan beberapa daerah lain telah. Sebagian muatan-muatan dari perda-perda syariah di Indonesia tersebut sangat bertentangan dengan ketentuan hak asasi manusia. Selain itu Peraturan Daerah bernuansa syariah Islam juga kerap telah melanggar hak-hak perempuan dan hak-hak kebebasan sipil. Contohnya perihal cara berpakaian yang sangat dibatasi, serta ruang dan waktu gerak dari perempuan di ranah publik sangat dibatasi dan dibelenggu. Data yang dikemukakan Komnas Perempuan mencatat telah terjadi 46 kasus Pelanggaran Terhadap Perempuan hingga tahun 2005 atas pemberlakuan ini (Republik Indonesia 2006).

Perda bernuansa syariah Islam ini juga telah diindikasikan berpotensi menimbulkan bentuk-bentuk diskriminasi bagi masyarakat di daerah. Seperti contohnya adanya diskriminasi bagi pemeluk agama yang lain, di bulukumba, Sulawesi yang terdapat Perda yang mewajibkan setiap orang untuk belajar membaca Alquran dan di berbagai daerah lainnya yang sama-sama demikian. Hal demikian tentu sangat beretentangan dengan konsepi hak asasi manusia sehingga menjadi sorotan komunitas Hak Asasi Manusia Internasional. Fenomena ini bisa dilihat dari lahirnya peraturan daerah yang berperspektif syariah Islam, artinya memuat syariat Islam sebagai isi muatan peraturan daerah, baik pada tingkat propinsi maupun kabupaten/kota. Formalisasi syariah Islam dalam materi muatan Perda sangat beragam dari kadar syariah Islamnya yang paling rendah yang hanya mengatur masalah ibadah seperti minuman keras, pelacuran, pemberdayaan ZIS (Zakat, Infak, dan Sedekah), mengenai persoalan Jum'at khusyuk, dan keharusan bisa baca tulis al-Qur'an, serta keharusan berbusana Muslim. Sampai pada kadar syariah Islam tertinggi yaitu hukum 
pidana Islam yang hanya terjadi di Aceh, seperti penerapan hukum cambuk bagi penjudi dan pelaku mesum/khalwat (wanita dan laki-laki dewasa berdua-duaan di tempat sepi, ada juga di daerah lain yakni di Kota Tangerang dengan perda pelarangan wanita keluar malam (Kamil 2007).

Formalisasi syariah Islam ke dalam muatan Perda bukan hanya tidak sesuai dengan prinsip ketatanegaraan Indonesia sebagai negara yang menganut sistem demokrasi, namun juga dianggap tidak sesuai dengan ketentuan hak asasi manusia, karena bertentangan dengan prinsip-prinsip hak asasi manusia. Materi muatan yang bersumber dari syariah Islam hanyalah mengacu pada sudut pandang salah satu agama saja yakni Islam, hal ini sangatlah bertentangan dengan prinsip non diskriminasi dan prinsip kesetaraan.

Dalam konsep hak asasi manusia telah dicantumkan bahwa dalam suatu peraturan perundang-undangan tertulis, tidak terkecuali peraturan daerah dilarang mencantumkan salah satu materi muatan yang bersudut pandang agama dalam hal ini syariah Islam yang bersumber dari agama Islam. Materi muatan yang bersudut pandang syariah Islam telah mengandung unsur-unsur pembedaan less favourable bagi seseorang baik secara langsung maupun secara tidak langsung. Yang dimaksud dengan dampak secara langsung disini ialah dampak yang dirasakan langsung oleh diri seseorang tersebuut dari sebuah ketentuan hukum. Sedangkan dampak secara tidak langsung adalah muncul ketika dampak hukum atau dalam tataran implementasi merupakan bentuk diskriminasi walaupun hal itu tidak ditujukan untuk tujuan diskriminasi.

\section{Konteks Ketatanegaraan Indonesia}

Sejak bermunculan perda-perda syariah, dalam implementasinya banyak ditemukan sejumlah perda yang materi muatannya bersinggungan dengan materi muatan hak asasi manusia yang dimuat dalam konstitusi. Sebagian kalangan memandang bahwa perda-perda ini bertentangan dengan dengan hak-hak asasi manusia yang telah secara tegas dimuat dalam UUD NRI 1945. Hak asasi yang yang dimaksud dalam UUD 1945 adalah:

1. Hak untuk hidup dan mempertahankan kehidupannya (Pasal $28 \mathrm{~A}$ )

2. Hak atas pengakuan, jaminan, perlindungan, dan kepastian hukum yang adil serta perlakuan yang sama dihadapan hukum (Pasal 28D ayat (1))

3. Hak memperoleh kesempatan yang sama dalam pemerintahan (Pasal 28D ayat (3))

4. Hak atas kebebasan memluk agama dan beribadah menurut keyakinan agamanya (Pasal 28E ayat (1))

5. Hak atas kebebasan meyekini keprcayaan, menyatakan pikiran dan sikap, sesuai dengan hati nuraninya (Pasal 28E ayat (2))

6. Hak atas perlindungan diri pribadi, keluarga, kehormatan, martabat, dan harta benda 
yang di bawah kekuasaannya serta berhak atas rasa aman dan perlindungan dari ancaman ketakutan untuk berbuat atau tidak berbuat sesuatu yang merupakan hak asasi (Pasal 28G)

7. Hak bebas dari perlakuan yang bersifat diskriminatif atas dasar apapun dan berhak mendapatkan perlindungan terhadap- perlakuan yang bersifat diskriminatif itu (Pasal 28 l ayat (2))

Selain melanggar ketentuan Hak Asasi manusa dalam konstitusi, Perda Syariah ini juga bertentangan dengan asas materi muatan Peraturan daerah yang ketentuannya telah di atur dalam Undang-undang Nomor 12 Tahun 2011 tentang Pembentukan Peraturan Perundang-Undangan. Sebut saja Perda Kota Malang No 8 Tahun 2005 Tentang Larangan Pelacuran. Materi-materi dalam Perda ini sangat bertentangan dengan asas-asas Pembentukan dan asas-asas materi muatan Peraturan Daerah yakni Asas kemanusiaan adalah bahwa setiap materi puatan peraturan perundang-undangan harus mencerminkan pelindungan dan penghormatan hak asasi manusia serta harkat dan martabat setiap warga negara dan penduduk Indonesia secara proporsional, namun dengan diterapkannya Perda ini, sisi perlindungan dan penghormatan HAM telah tercederai. Alih-alih melindungi dan mengayomi, justru Perda ini telah berbuat sewenang-wenang dengan menuduh perempuan sebagai pelacur tanpa adanya bukti yang jelas, karena Perda ini telah menginstruksikan untuk meakukan penangkapan atas dasar kecurigaan dan tidaklah mencerminkan asas presumption of innocent (praduga tak bersalah).

Perda Syariah sesungguhnya sulit untuk dilakukan uji materil, karena batu ujinya adalah UUD NRI 1945. Mahkamah Agung yang merupakan lembaga negara yang hanya memiliki kewenangan untuk peraturan di bawah Undang-undang, tidak memungkinkan untuk mengujinya. Kalaupun dipaksakan untuk mengujinya, Mahkamah Agung hanya dapat menggunakan batu uji Undang-Undang Hak Asasi Manusia. Sedangkan Mahkamah Konstitusi juga tidak memungkinkan untuk kemudian mengujinya meskipun materi muatan Peraturan daerah bersinggungan dengan materi muatan Konstitusi, karena posisi Peraturan daerah berada di bawah Undang-Undang (Huda 2014).

\section{Perspektif Siyasah Dusturiyyah}

Secara etimologis kata siyasah berasal dari akar kata yang artinya ساس-سياسة mengatur, mengurus, mengendalikan atau membuat keputusan. Dalam Kamus al-Munjid, kata siyasah diartikan sebagai pengambilan keputusan, pemerintahan, pembuat kebijakan, pengawasan, pengurusan, atau perekayasaan. Selanjutnya al-siyasah terkadang diartikan sebagai memimpin sesuatu dengan cara yang membawa kemaslahatan dan menjauhkannya dari kemudharatan. Sedangkan pengertian siyasah secara istilah adalah ilmu pemerintahan 
untuk mengendalikan tugas dalam negeri dan luar negeri, yaitu politik dalam negeri dan pilitik luar negeri serta kemasyarakatan, yakni mengatur kehidupan atas dasar istiqomah dan keadilan (Pulungan 1999).

Siyasah atau dapat juga dimaknai sebagai politik hukum Islam merupakan pembahasan yang mengatur urusan umum dalam pemerintahan yang berdasarkan nilai-nilai Islam. Pengaturan tersebut dengan menciptakan kemaslahatan dan menolak atau mencegah kemudharatan. Kemudian yang dimaknai dengan urusan umum dalam pemerintahan yang bernafaskan Islam merupakan segala sesuatu tuntutan zaman, sistem dan kehidupan sosial, baik yang berupa hukum, undang-undang, keuangan, peradilan dan lembaga eksekutif dan juga urusan undang-undang hubungan luar negeri dan dalam negeri atau maka untuk mengatur semua urusan ini, teori dan prinsip dasarnya serta membuat peraturan-peraturannya yang sesuai dengan dasar hukum adalah politik hukum Islam (Khalaf 1994).

Dustŭrīadalah prinsip pokok bagi pemerintahan negara manapun seperti halnya yang terdapat dalam peraturan perundang-undangan dan adat istiadatnya. Abu A'la al-Maududi mengartikan kata dustur dengan : Suatu dokumen yang memuat prinsip-prinsip pokok yang menjadi landasan pengaturan suatu negara. Sehingga dari dua istilah ini dapat disimpulkan bahwa kata dustur sama dengan constitution dalam bahasa inggris, atau Undang-Undang Dasar dalam bahasa Indonesia, kata-kata "dasar" dalam bahasa Indonesia tersebut tidaklah mustahil bila berasal dari kata dustur tersebut di atas (Iqbal 2007).

Terdapat istilah fiqh dustŭrī dalam kurikulum beberapa Fakultas Syari'ah, yang dimaksud dustŭrī adalah (Ghorbal 1965):

$$
\text { الاستور هو القواعد الأساسية للحكم فى أية دولة كما تدل عليها قو انينها }
$$

Dengan demikian, siyasah dusturiyyah adalah bagian dari Fikih Siyasah yang membahas masalah perundang-undangan negara agar sejalan dengan nilainilai syari'at. Artinya, undang-undang itu mengacu terhadap konstitusinya yang tercermin dalam prinsip-prinsip Islam dalam hukum-hukum syari'at yang disebutkan di dalam al-Qur'an dan siyasah dusturiyyah membahas peraturan dan perundang-undangan yang bertujuan demi kemaslahatan manusia dan terpenuhinya kebutuhan manusia. Persoalan mengenai siyasah dusturiyyah tidak dapat dilepaskan dari dalil-dalil kully, yakni baik al-Qur'an, Hadist, maqāșid alsyari'ah serta semangat Islam dalam mengatur masyarakat (Djazuli 2007).

Suatu kebijakan dari pemerintah berupa keputusan, peraturan perundang-undangan atau hukum yang ditetapkan pada satu waktu tertentu dapat diganti atau dirubah. Perubahan itu perlu apabila ia tidak lagi relevan dengan kenyataan politik yang ada sebab perubahan zaman, tempat, situasi, kondisi sosial masyarakat yang ada pada saat itu. Akan tetapi perubahan tersebut tetap berorientasi pada nilai-nilai dan jati diri manusia serta 
kemanusiaan. Muatannya tidak bertentangan secara substansial dengan nash-nash syariat yang bersifat universal di setiap zaman dan tempat (șālih likulli zamān wa makān). Perubahan itu haruslah menjawab permasalahan yang ada dan mampu menampung aspirasi serta konsdisi sosial masyarakat yang ada semata-mata demi mewujudkan kemaslahatan rakyat.

Para ulama mengkategorikan ajaran Islam menjadi dua bagian yakni ajaran dasar dan ajaran non dasar. Ajaran dasar Islam termuat dalam Alquran dan hadis mutawatir, di dalamnya tercantum teks-teks yang bersifat mutlak, absolut, dan tidak dapat diubah. Sedangkan ajaran non dasar termuat dalam berbagai ijtihad para ulama zaman dahulu sampai sekarang, sifat dari ijtihad sendiri adalah relatif maka kebenarannya bukan absolut dan bisa berubah secara konstekstual dan inilah yang kemudian dinamakan fikih (Mulia 2010).

Ajaran islam menempatkan manusia sejajar kedudukannya dengan manusia yang lain. Dalam hal perbedaan antar individu islam mendasarkan pada keimanan dan ketaqwaan. Islam sebagai suatu sistem telah menempatkan manusia pada posisi yang tinggi sebagai makhluk yang mulia dan terhormat. Dengan demikian, perlindungan dan penghormatan menusia merupakan suatu keharusan dari ajaran Islam itu sendiri yang harus dilaksananakan oleh umatnya terhadap sesama manusia di dunia tanpa terkecuali. Dalam prinsip nomokrasi Islam hak asasi manusia diakui dan dilindungi secara penuh. Oleh karena itu ada dua prinsip utama yakni pengakuan hak asasi manusia serta perlindungan hak asasi manusia (Azhary 2010). Prinsip-prinsip tersebut telah ditegaskan secara gamblang dalam Alquran:

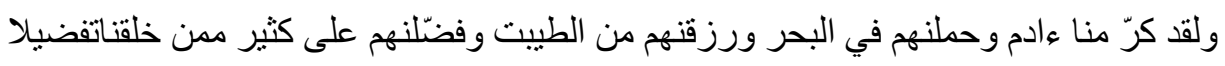

Prinsip hak-hak asasi manusia dalam hukum Islam berdasarkan al-Qur'an dan Sunnah, Muhammad Tahir Azhary merumuskannya sebagai berikut (Azhary 2010):

Tabel 1

Hak-Hak Asasi Manusia dalam Hukum Islam berdasarkan Alquran dan as-Sunnah

\begin{tabular}{lll} 
KEMULIAAN & HAK-HAK PRIBADI & KEBEBASAN \\
\hline Pribadi & Persamaan & Beragama \\
Masyarakat & Martabat & Berpikir \\
Politik & Kebebasan & Menyatakan pendapat \\
& & Berbeda pendapat \\
& Memiliki harta benda \\
& Berusaha \\
& Memilih Pekerjaan \\
& Memilih Tempat Kediaman
\end{tabular}

al-ạ̣kām vol. 4, Nomor 2, 2019 
Apabila diamati dari tipologi masyarakat Islam Indonesia mengenai pemberlakuan hukum Islam di Indonesia, sedikitnya terdapat dua kelompok, yakni (Azizy 2002): (1) Kelompok yang menekankan pada pendekatan normatif (formalisme), dan (2) Kelompok yang menekankan pada pendekatan kultural (budaya). Menurut pendapat kelompok yang setuju dengan formalisasi, hukum Islam harus diterapkan kepada mereka yang sudah mengucapkan dua kalimat syahadat atau sudah masuk Islam. Dengan dianutnya ajaran agama Islam, kelompok ini memandang wajib adanya menjalankan hukum Islam dalam kehidupan sehari-hari. Oleh karena itu proses kehidupan politik, termasuk partai politik adalah sebagai alat untuk menerapkan Islam secara normatif dan formal. Konsekuensinya, pelaksanaan Piagam Jakarta menjadi persoalan yang sangat besar dan serius, yang harus terus diperjuangkan. Oleh karena itu karena merupakan satu-satunya cara untuk penerapan hukum Islam secara formal (Huda 2014).

Tipologi kelompok masyarakat Indonesia yang kedua adalah pendekatan kultural. Menurut pendapat kelompok ini bahwa yang terpenting bukanlah formalisasi penerapan hukum Islam atau pendekatan normatif ideologis. Yang lebih penting dari itu semua adalah penyerapan nilai-nilai hukum Islam ke dalam masyarakat (pendekatan substansial) (Anwar 1995). Dengan heterogenitas masyarakat Indonesia telah menciptakan pluralisme dan dualisme hukum menjadi ganjalan bagi reformasi hukum. Kuatnya tingkat ketergantungan pada produk hukum warisan Hindia Belanda dilihat dari bebrapa aturan perundangundangan yang merupakan warisan dari penjajahan kolonila Belanda. Hal ini menimbulkan sebuah konsekuensi logis yakni terjadinya pengelompokan hukum: (1) kelompok pembela hukum adat, (2) kelompok pembela hukum Islam, dan (3) kelompok pembela hukum Belanda (Anwar 1995).

Menurut Jimly Asshiddiqie, syari"at Islam haruslah dan wajib untuk diberlakukan, dan pada dasarnya syari"at Islam berlaku sampai kapanpun bagi kalangan umat Islam. Akan tetapi kedudukan syari"at Islam tidak perlu untuk diperjuangkan secara politik, karena sejatinya syri"at Islam itu melekat dengan sendirinya seiring dianutnya ajaran agama Islam oleh sebagian besar masyarakat Indonesia. Syari"at Islam merupakan jalan hidup dan berlaku bagi seluruh umat Islam terlepas dari ada atau tidaknya negara. Syari"at Islam menyangkut hukum tertinggi, yakni keyakinan manusia atas Kedaualatan Allah SWT atas dirinya, sedangkan urusan kenegaraan merupakan sebagian kecil saja dari urusan manusia (Asshiddiqie 2008).

\section{Kesimpulan}

Terpenting dalam hal ini bukanlah formalisasi penerapan hukum Islam atau pendekatan normatif ideologis. Yang lebih penting dari itu semua adalah penyerapan nilainilai hukum Islam ke dalam masyarakat. Ada atau tidaknya Perda Syari"ah bukanlah sesuatu 
yang sangat urgen. Jauh dari itu, syari"at Islam tetap akan tegak dan tumbuh bersemi dengan subur karena sampai kapanpun bagi umat Islam, syari"at Islam merupakan jalan hidup dan berlaku bagi seluruh umat Islam terlepas dari ada atau tidaknya negara. Harus terus dilakukan sosialisasi bahwa syari"at Islam bukan hanya sebatas pada penampakan simbol-simbol agama di area publik seperti pemakaian jilbab atau memakai busana muslim. Namun sebenarnya harus mencakup aturan tentang antikorupsi, kesejahteraan masyarakat, pelestarian lingkungan, perlindungan HAM, serta masalah-masalah yang lebih konkrit dan realistis dalam bermasyarakat, berbangsa dan bernegara.

Hendaknya pemberlakuan syariat Islam di daerah-daerah harus memperhatikan ketentuan-ketentuan yang berlaku dalam sistem ketatanegaraan Indonesia. Bahwa era desentralisasi/otonomi daerah telah menjamin dan mengakui adanya pluralisme hukum nasional, sehingga sangat mungkin tradisi-tradisai hukum yang selama ini hidup dan berkembang bisa diangkat menjadi materi-materi dalam berbagai peraturan daerah, namun harus tetap mengacu kepada peraturan-peraturan yang lebih tinggi tingkatannya. Dengan demikian terhindar dari adanya konflik sehingga dapat berlaku secara efektif dan efisien.

\section{Daftar Pustaka}

Anwar, M. Syafei. 1995. Pemikiran Dan Aksi Islam Indonesia: Sebuah Kajian Tentang Cendekiawan Muslim Orde Baru. Jakarta: Paramadina.

Asshiddiqie, Jimly. 2008. Menuju Negara Hukum Yang Demokratis. Jakarta: Sekretariat Jenderal dan Kepaniteraan Mahkamah Konstiusi.

Azhary, Muhammad Tahir. 2010. Negara Hukum: Suatu Studi Tentang Prinsip-Prinsipnya Dilihat Dari Segi Hukum Islam, Implementasinya Pada Periode Negara Madinah Dan Masa Kini. Jakarta: Kencana.

Azizy, A. Qodri. 2002. Eklektisisme Hukum Nasional Kompetisi Antara Hukum Islam Dan Hukum Umum. Yogyakarta: Gama Media.

Djazuli, A. 2007. Fiqh Siyasah, Implementasi Kemaslahatan Umat Dalam Rambu-Rambu Syari'ah. Jakarta: Kencana.

Felix, Rega. 2011. “Eksistensi Perda Syariah Dalam Sistem Hukum Nasional.” 2011. https:// regafelix.wordpress.com/2011/12/15/eksistensi-perda-syariah-dalam-sistemhukum-nasional/.

Ghorbal, Muhammad Syafieq. 1965. Al-Mansu'ah Al-Arobiyah Al-Muyassarah. Kairo: Darul Qalam.

Huda, Ni'matul. 2014. Perkembangan Hukum Tata Negara: Perdebatan Dan Gagasan Penyempurnaan. Yogyakarta: FH UII Press.

Iqbal, Muhammad. 2007. Fiqh Siyasah: Kontekstualisasi Doktrin Politik Islam. Jakarta: Gaya Media Pratama.

al-aḥ̂ām vol. 4, Nomor 2, 2019 
Jati, Wasisto Raharjo. 2013. "Permasalahan Implementasi Perda Syariah Dalam Otonomi Daerah." Jurnal Al Manahij VII (2).

Kamil, Sukron. 2007. Dampak Perda Syariah Terhadap Kebebasan Sipil, Hak-Hak Perempuan, Dan Non Muslim. Jakarta: CSRC UIN Jakarta dan KAS.

Khalaf, Abdul Wahab. 1994. Politik Hukum Islam. Yogyakarta: Penerbit Tiara Wacana.

Mulia, Musdah. 2010. Islam Dan Hak Asasi Manusia: Konsep Dan Implementasi. Yogyakarta: Naufan Pustaka.

Pulungan, Suyuti. 1999. Fiqh Siyasah: Ajaran, Sejarah Dan Pemikiran. Jakarta: Raja Grafindo Persada.

Republik Indonesia. 2006. Undang-Undang No. 11 Tahun 2006 Tentang Pemerintahan Aceh. Indonesia.

-- - 2011. Undang-Undang No. 12 Tahun 2011 Tentang Pembentukan Peraturan Perundang-Undangan. Indonesia.

Suntana, Ija. 2014. Politik Hukum Islam. Bandung: CV Pustaka Setia. 